\title{
PHYSIOLOGICAL BASIS OF WATER STRESS TOLERANCE IN SOYBEAN
}

\author{
K. K. Sarkar', M. A. Mannan ${ }^{1 *}$, M. M. Haque ${ }^{1}$ and J. U. Ahmed ${ }^{2}$ \\ ${ }^{1}$ Department of Agronomy, Bangabandhu Sheikh Mujibur Rahman Agricultural University, Gazipur-1706, Bangladesh. \\ ${ }^{3}$ Department of Crop Botany, Bangabandhu Sheikh Mujibur Rahman Agricultural University, Gazipur-1706 \\ *Corresponding author: mannanbsmrau@yahoo.com
}

Key words: Physiology, water stress, tolerance, soybean

\begin{abstract}
An experiment was conducted to study the effects of water stress on physiological parameters associated to drought tolerance in soybean at the Department of Agronomy, Bangabandhu Sheikh Mujibur Rahman Agricultural University, Gazipur, Bangladesh during January to April, 2015. Four soybean genotypes namely i) BU Soybean 1 ii) Binasoybean 1 iii) Galarsum and iv) BARI Soybean 5 were grown in two watering regimes viz. control (80\% of the field capacity) and water stress (50\% of the field capacity). Genotypic variability was found in water stress tolerance in soybean. Highest accumulation of leaf proline, sugar and water content and lower accumulation of malondialdehyde were found in Binasoybean 1 compared to other genotypes. Lowest yield reduction was found in Binasoybean 1. Binasoybean 1 showed relatively higher drought tolerance whereas BARI Soybean 5 was found susceptible to yield. It was found that higher water stress tolerance in Binasoybean 1 was associated with better water relations and higher accumulation of sugar and proline and lower accumulation of malondialdehyde content in leaf.
\end{abstract}

\section{Introduction}

Water deficit is the most severe abiotic stress limiting plant growth and crop production (Moussa, 2011; Rohbakhsh, 2013). With the change in global climate, the soil moisture balance and available moisture in soil is going to change and the frequency of regional drought will increase (Fuhrer, 2003). Water deficit induces several morphological, physiological, biochemical and molecular responses in several crop plants, which would help them to adapt to such limiting environmental conditions (Arora et al., 2002). Mechanisms of drought tolerance, especially at low water stress, involve processes at the cellular level, the most important being osmotic adjustment and protection of the membrane system. In order to keep osmotic balance, specific types of organic molecules (such as soluble sugars, proline etc) are accumulated in the cytoplasm. Those compounds protect plants against stresses by cellular adjustment through the protection of membranes integrity and enzymes stability (Farooq et al., 2009). So, aim of the research work was to analyze the changes of physiological parameters those are associated with drought tolerance in soybean under water stress

\section{Materials and Methods}

The experiment was conducted at the Department of Agronomy, Bangabandhu Sheikh Mujibur Rahman Agricultural University, Gazipur, Bangladesh. Four soybean genotypes namely i) BU Soybean 1 ii) Binasoybean 1 iii) Galarsum and iv) BARI Soybean 5 were grown in plastic pots of diameter $(24 \mathrm{~cm}) \mathrm{X}$ height $(30 \mathrm{~cm})$ during January to April, 2015. The soil used in the pot was clay loam in texture and poor fertility status. The $\mathrm{pH}$ of the soil was 7.1 , organic carbon $0.60 \%$, total $\mathrm{N}$ $0.05 \%$, available P $0.08 \mathrm{mg} / 100 \mathrm{~g}$ dry soil, exchangeable $\mathrm{K} 0.33 \mathrm{cmol}_{\mathrm{c}} \mathrm{kg}^{-1}$ dry soil and CEC 14.58 $\mathrm{cmol}_{\mathrm{c}} \mathrm{kg}^{-1}$ dry soil. Compost ( $1 / 4$ th of the soil volume) and $0.27-0.28-0.20 \mathrm{~g}$ of urea, triple super phosphate and muriate of potash per pot for supplying $\mathrm{N}, \mathrm{P}_{2} \mathrm{O}_{5}$ and $\mathrm{K}_{2} \mathrm{O}$, respectively were 
Sarkar et al.

incorporated uniformly into the soil. The compost was from cow dung which contained $0.8 \% \mathrm{~N}, 0.6 \%$ $\mathrm{P}_{2} \mathrm{O}_{5}$ and $1.0 \% \mathrm{~K}_{2} \mathrm{O}$ on dry weight basis. Ten bold seeds were sown in each plastic pot containing about $12 \mathrm{~kg}$ air dried soil. After seedling establishment, six uniform and healthy plants were allowed to grow in each pot. Two watering regimes of the plants viz. control (80\% of the field capacity) and water stress (50\% of the field capacity) were maintained from at $1^{\text {st }}$ trifoliate growth stage i. e., 14 days after sowing upto maturity. The experiment was designed at Factorial Completely Randomized (CRD) with three replications. Relative water content, proline, total sugar and malondialdehyde (MDA) content of leaf were recorded at 15, 30 and 45 days after water stress. The uppermost fully developed leaves were collected from each plant and the relative water content (RWC), proline, malondialdehyde (MDA) and total sugar were measured according to Schonfeld et al.(1988), Bates et al. (1973), Health \& Packer (1968) and Somogyi (1952), respectively. Normal management practices were applied for all treatments. At maturity two plants were collected from each pot. Data on number of pod/plant, number of seed/pod, 100 seed weight and seed yield/plant were recorded. Seed yield per plant was adjusted at $14 \%$ moisture content. The recorded data were statistically analyzed and the treatment means were compared by Least Significance Difference (LSD) test (Gomez \& Gomez, 1984)

\section{Results and Discussion}

\section{Relative water content}

The effect of water stress on relative water content (RWC) of the genotypes varied significantly at 15 , 30, 45 days after drought imposition (Table 1). The RWC both in control and water stress condition was recorded highest in Binasoybean 1, while the lowest in BU Soybean 1 at 15 days after drought imposition. Relative (per cent of control) water content of the genotypes ranged from 93.01 to $95.25 \%$ at water stress. Highest relative water content was obtained from Binasoybean1 (95.25\%), followed by Galarsum $(94.81 \%)$ and BU Soybean $1(94.05 \%)$ while lowest in BARI Soybean $5(93.01 \%)$. The reduction of the RWC due to water stress was lower in Binasoybean $1(4.75 \%)$, while that was higher in BARI Soybean 5 (6.99\%). At 30 days, the RWC both in control and water stress was recorded highest in Binasoybean 1, while the lowest in BU Soybean 1. Relative (per cent of control) water content of the genotypes at different growth stages ranged from 85.36to $92.18 \%$ at water stress. Highest relative water content was obtained from Binasoybean 1 (92.18\%), followed by Galarsum $(89.82 \%)$ and BU Soybean $1(86.19 \%)$ and lowest in BARI Soybean $5(85.36 \%)$. The reduction of the RWC due to water stress was lower in Binasoybean $1(7.82 \%)$, while higher in BARI Soybean 5 (14.6\%). At 45 days, the RWC both in control and water stress condition was recorded highest in Galarsum and Binasoybean 1, respectively, while the lowest in Binasoybean 1 and BU Soybean 1, respectively. Relative water content of the genotypes ranged from 68.28 to $92.97 \%$ at water stress. Highest relative water content was obtained from Binasoybean 1 (92.97\%), followed by Galarsum $(85.17 \%)$ and BU Soybean $1(69.11 \%)$ and lowest in BARI Soybean $5(68.28 \%)$. The reduction of the RWC due to water stress was lower in Binasoybean 1 (7.03\%), while that was higher in BARI Soybean $5(31.72 \%)$. The reduction in leaf water was provoked by the water deficiency in soil, in which the water stress simulated artificially in this experiment cause as direct consequence changes in leaf relative water content reported as Verslues et al. (2006). Velu and Palanisami (2002) also reported that water stress significantly reduced relative water content of the plant.

Table 1.Relative water content (RWC \%) of soybean genotypes as affected by water stress at different days after water stress (DAWS)

\begin{tabular}{|c|c|c|c|c|c|c|}
\hline \multirow[t]{2}{*}{ Genotypes } & \multicolumn{2}{|c|}{15 DAWS } & \multicolumn{2}{|c|}{30 DAWS } & \multicolumn{2}{|c|}{45 DAWS } \\
\hline & Control & Water stress & Control & Water stress & Control & Water stress \\
\hline BU Soybean 1 & 87.37 & $\begin{array}{c}82.17 \\
(94.05)\end{array}$ & 78.05 & $\begin{array}{c}67.27 \\
(86.19)\end{array}$ & 81.31 & $\begin{array}{c}56.19 \\
(69.11)\end{array}$ \\
\hline
\end{tabular}


Physiological Basis of Water Stress Tolerance in Soybean

\begin{tabular}{lcccccc} 
Binasoybean 1 & 90.37 & 86.08 & 82.38 & 75.94 & 77.37 & 71.93 \\
& & $(95.25)$ & & $(92.18)$ & & $(92.97)$ \\
Galarsum & 90.02 & 85.35 & 80.83 & 72.60 & 82.79 & 70.51 \\
& & $(94.81)$ & & $(89.82)$ & & $(85.17)$ \\
BARI Soybean 5 & 88.88 & 82.67 & 79.90 & 68.20 & 82.64 & 56.43 \\
& & $(93.01)$ & & $(85.36)$ & $(68.28)$ \\
\hline LSD $(0.05)$ & 5.53 & & 7.30 & 7.20 \\
CV $(\%)$ & 3.68 & 5.51 & 7.20 \\
\hline
\end{tabular}

Values in parenthesis indicate \% values of control

\section{Proline content}

The effect of water stress on proline content of the genotypes varied significantly at 15,30 and 45 days after drought imposition (Table 2). At 15 days, the highest proline content in control condition was in BARI Soybean 5 and water stress in Binasoybean 1, while the lowest was in BU Soybean. Relative (per cent of control) proline content of the genotypes ranged from 108.82 to $144.02 \%$ under water stress. Highest relative proline content was obtained from Binasoybean 1 (144.02\%), followed by Galarsum (119.97\%) and BU Soybean $1(110.73 \%)$ and it was lowest in BARI Soybean 5 $(108.82 \%)$. The increase of proline content due to water stress was higher in Binasoybean 1 $(144.02 \%)$, while that was lower in BARI Soybean 5 (108.82\%). At 30 days, the proline content both in control and water stress was recorded highest in Galarsum and Binasoybean 1, respectively, while the lowest was in BU Soybean1. Relative (per cent of control) proline content of the genotypes ranged from 148.46 to $355.18 \%$ at water stress. Highest relative proline content was obtained from Binaoybean 1 (355.18\%), followed by BU Soybean 1 (201.92\%) and Galarsum (198.50\%) and it was lowest in BARISoybean $5(148.46 \%)$. The increase of the proline content due to water stress was higher in Binasoybean 1, while that was lower in BARI Soybean 5. At 45 days, the proline content at water stress was recorded highest in Binasoybean 1. Relative (per cent of control) proline content of the genotypes ranged from 96.12 to $186.66 \%$ under water stress. Highest relative proline content was obtained from Binasoybean 1 (186.66\%), followed by BARI Soybean $5(116.37 \%)$ and BU Soybean $1(105.93 \%)$ and lowest in Galarsum (96.12\%). The increase of the proline content due to water stress was higher in Binasoybean 1, while that was lower in Galarsum. The proline accumulation is a metabolic response characteristic of plants under abiotic stresses, it being showed the increase in this experiment because the free proline work as osmotic adjustor that reduce the negative effects provoked in the plants under adverse conditions (Kishor et al.,1995), besides promote higher resistance in cells under these circumstances (Zhu and Xiong, 2002). The proline is synthesized from glutamate and ornitine, in which the production of this organic solute, under conditions of the water shortage, occur at major part from glutamate (Delauney and Verma, 1993).

Table 2. Leaf proline content ( $\mathrm{mg} \mathrm{g}^{-1}$ fresh weight) of soybean genotypes as affected by water stress at different days after water stress (DAWS)

\begin{tabular}{|c|c|c|c|c|c|c|}
\hline \multirow[t]{2}{*}{ Genotypes } & \multicolumn{2}{|r|}{15 DAWS } & \multicolumn{2}{|c|}{30 DAWS } & \multicolumn{2}{|c|}{45 DAWS } \\
\hline & $\begin{array}{l}\text { Cont } \\
\text { rol }\end{array}$ & Water stress & Control & Water stress & Control & Water stress \\
\hline BU Soybean 1 & 1.77 & $\begin{array}{c}1.96 \\
(110.73)\end{array}$ & 1.04 & $\begin{array}{c}2.10 \\
(201.92)\end{array}$ & 1.18 & $\begin{array}{c}1.25 \\
(105.93)\end{array}$ \\
\hline Binasoybean 1 & 1.84 & $\begin{array}{c}2.65 \\
(144.02)\end{array}$ & 1.27 & $\begin{array}{c}4.51 \\
(355.18)\end{array}$ & 0.90 & $\begin{array}{c}1.68 \\
(186.66)\end{array}$ \\
\hline Galarsum & 1.88 & 2.25 & 2.00 & 3.97 & 1.29 & 1.24 \\
\hline
\end{tabular}


Sarkar et al.

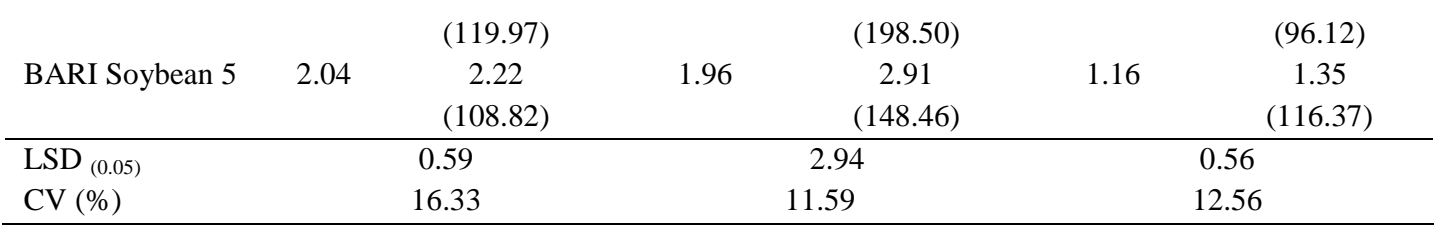

Values in parenthesis indicate \% values of control

\section{Malondialdehyde (MDA) content}

The malondialdehyde (MDA) content of the genotypes was significantly affected by drought at 15 days after water stress (Table 3). The malondialdehyde (MDA) content in control was highest in Galarsum, while the lowest in BARI Soybean 5. Relative (per cent of control) MDA content of the genotypes ranged from 116.21 to $140.86 \%$ at water stress. Highest relative MDA content was obtained from BU Soybean 1 (140.86\%), followed by BARI Soybean $5(137.23 \%)$ and Galarsum $(120.71 \%)$ and lowest in Binasoybean 1 (116.21\%). The increase of MDA content due to water stress was higher in BU Soybean 1, while that was lower in Binasoybean 1. At 30 days after drought imposition, the MDA content under water stress was recorded highest in BARI Soybean 5, while the lowest was in Binasoybean 1. Relative (per cent of control) MDA content of the genotypes ranged from 125.26to $149.69 \%$ at 50\% field capacity. Highest relative MDA content was obtained from BARI Soybean 5 (149.69\%), followed by Galarsum (142.91\%) and BU Soybean $1(134.04 \%)$ and lowest in Binasoybean $1(125.26 \%)$. The increase of MDA content due to water stress was higher in BARI Soybean 5, while that was lower in Binasoybean 1. At 45 days, the MDA content was recorded highest in BU Soybean 1, while the lowest in BARI Soybean 5. Relative (per cent of control) MDA content of the genotypes ranged from 111.78 to $121.94 \%$. The maximum relative MDA content was obtained from BARI Soybean 5 (121.94\%), followed by Galarsum (117.73\%) and Binasoybean 1 $(111.86 \%)$ and it was lowest in BU Soybean $1(111.78 \%)$. The increase of MDA content due to water stress was higher in BARI Soybean 5, while lower in BU Soybean 1. The relative MDA content was significantly higher in water stress condition than control in all the genotypes In the present investigation, the lower relative values of MDA in Binasoybean 1 indicate that at cellular level this genotype is better equipped with efficient free radical quenching system that offers protection against oxidative stress.

\section{Total sugar content}

The effect of water stress on total sugar content varied significantly at 15 days after drought imposition (Table 4). The total sugar content in control condition was higher in BARI Soybean 5 while the lowest in Binasoybean 1. Relative sugar content (per cent of control) of the genotypes ranged from 104.15 to $136.03 \%$ at water stress condition.

Table 3. Malondialdehyde (MDA) (nmol g ${ }^{-1}$ fresh weight) content of soybean genotypes as affected by water stress at different days after water stress (DAWS)

\begin{tabular}{|c|c|c|c|c|c|c|}
\hline \multirow[t]{2}{*}{ Genotypes } & \multicolumn{2}{|c|}{15 DAWS } & \multicolumn{2}{|c|}{30 DAWS } & \multicolumn{2}{|c|}{45 DAWS } \\
\hline & Control & Water stress & Control & Water stress & Control & Water stress \\
\hline BU Soybean 1 & 11.50 & $\begin{array}{c}16.20 \\
(140.86)\end{array}$ & 18.65 & $\begin{array}{c}25.00 \\
(134.04)\end{array}$ & 49.65 & $\begin{array}{c}55.50 \\
(111.78)\end{array}$ \\
\hline Binasoybean 1 & 13.20 & $\begin{array}{c}15.34 \\
(116.21)\end{array}$ & 19.95 & $\begin{array}{c}24.99 \\
(125.26)\end{array}$ & 44.92 & $\begin{array}{c}50.25 \\
(111.86)\end{array}$ \\
\hline Galarsum & 14.00 & $\begin{array}{c}16.90 \\
(120.71)\end{array}$ & 18.55 & $\begin{array}{c}26.51 \\
(142.91)\end{array}$ & 43.59 & $\begin{array}{c}51.32 \\
(117.73)\end{array}$ \\
\hline BARI Soybean 5 & 11.20 & $\begin{array}{c}15.37 \\
(137.23) \\
\end{array}$ & 19.36 & $\begin{array}{c}28.98 \\
(149.69) \\
\end{array}$ & 40.28 & $\begin{array}{c}49.12 \\
(121.94) \\
\end{array}$ \\
\hline $\begin{array}{l}\operatorname{LSD}_{(0.05)} \\
\mathrm{CV}(\%)\end{array}$ & & $\begin{array}{l}4.12 \\
1.21\end{array}$ & & $\begin{array}{l}\text { NS } \\
0.56\end{array}$ & & $\begin{array}{l}3.84 \\
3.55\end{array}$ \\
\hline
\end{tabular}

Values in parenthesis indicate \% values of control 
The maximum relative total sugar content was obtained from BInasoybean 1 (136.03\%), followed by Galarsum (131.74\%) and BU Soybean 1 (105.65\%) and lowest in BARI Soybean 5 (104.15\%). At 30 days, the sugar content in control condition was recorded highest in BU Soybean 1, while the lowest in Binaoybean 1. Relative (per cent of control) sugar content of the genotypes ranged from 116.69 to $193.44 .11 \%$ at water stress condition. Highest relative total sugar content was obtained from Binasoybean 1 (193.44\%), followed by Galarsum (188.62\%) and BU Soybean 1 (123.81\%) and lowest in BARI Soybean 5 (116.69\%). The increase of the sugar content due to water stress was higher in the Binaoybean 1, while lower in BARI Soybean $5(116.58 \%)$. The effect of water stress was not significant at 30 days after drought imposition. At 45 days after, the sugar content in control condition was recorded highest in Galarsum, while the lowestin Binasoybean 1. Relative sugar content of the genotypes ranged from 117.63 to $136.46 \%$ at water stress while while Binasoybean 1 $(136.46 \%)$, followed by Galarsum (124.01\%) and BU Soybean $1(122.36 \%)$ and lowest in BARI Soybean $5(117.63 \%)$. . The total soluble sugars content in soybean leaves significantly increased under drought stress. These results are in accordance with Abass and Mohamed (2011) who reported that the drought condition caused significant increase in the soluble sugars content in shoot of common bean plants.

Table 4. Total sugar content ( $\mathrm{mg} \mathrm{g}^{-1}$ fresh weight) of soybean genotypes as affected by water stress at different days after water stress (DAWS)

\begin{tabular}{l|cc|c|c|c|c}
\hline \multirow{2}{*}{ Genotypes } & \multicolumn{2}{|c|}{ 15 DAWS } & \multicolumn{2}{c|}{ 30 DAWS } & \multicolumn{2}{c}{ 45 DAWS } \\
\cline { 2 - 7 } & Control & Water stress & Control & Water stress & Control & Water stress \\
\hline BU Soybean 1 & 43.12 & 45.57 & 42.11 & 52.14 & 67.51 & 82.79 \\
& & $(105.65)$ & & $(123.81)$ & & $(122.63)$ \\
Binasoybean 1 & 37.75 & 51.35 & 24.40 & 47.20 & 65.39 & 89.23 \\
& & $(136.03)$ & & $(193.44)$ & & $(136.46)$ \\
Galarsum & 38.72 & 51.00 & 26.64 & 50.25 & 79.19 & 98.21 \\
& & $(131.74)$ & & $(188.62)$ & & $(124.01)$ \\
BARI Soybean 5 & 44.96 & 46.83 & 33.85 & 39.50 & 75.24 & 88.52 \\
& & $(104.15)$ & & $(116.69)$ & & $(117.63)$ \\
\hline LSD & & & NS & & 36.20 \\
CV $(\%)$ & & 10.93 & 12.10 & 15.04 \\
\hline
\end{tabular}

Values in parenthesis indicate \% values of control

\section{Number of pod}

The highest number of pod/plant under control was recorded in Galarsum (81.67) and the lowest in BU Soybean 1 (57.33). On the other hand, under water stress condition Binasoybean 1 produced the highest number of pod/plant (43.67) and the lowestin BARI Soybean 5 (26). Relative number of pod / plant of the genotypes ranged from 34.06 to $65.27 \%$ at water deficit condition. The maximum relative number of pod / plant was obtained from Binasoybean 1 (65.27\%), followed by BU Soybean 1 $(64.53 \%)$ and Galarsum (38.36\%) and lowest in BARI Soybean 5 (34.06\%). The significant reduction in number of harvested pod/plant under water stress may be attributed to the abscission of the reproductive structures. Ziska and Hall (1983) and Gwathmey and Hall (1992) reported similar results.

\section{Number of seed}

The highest number of seed/pod under control was recorded from BU Soybean 1 (2.03) and the lowest in BINA Soybean 1 (1.99). On the other hand, under water stress condition Binasoybean 1 produced the highest number of seed/pod (1.89) and the lowest from BARI Soybean 5 (1.59). Relative (percent of control) number of seed/pod of the genotypes ranged from 78.71 to $94.97 \%$ at water deficit condition. Highest relative number of seed/pod was obtained from oybean 1 (94.97\%), followed by 
Sarkar et al.

BU Soybean $1(90.15 \%)$ and Galarsum (81.19\%) and lowest in BARI Soybean 5 (78.71\%). The reduction in number of seed/pod and seed size under water stress treatments may be attributed to the limitation of dry matter partitioning to the reproductive sink or even seed formation factors as has been reported by Turk et al. (1980).

\section{0-seed weight}

The highest seed weight both under control and water stress condition was recorded in Binasoybean 1 (11.76 g and $10.26 \mathrm{~g}$ ) and the lowest in BARI Soybean 5 (11.21 g and 7.11 g). Relative weight of 100 -seeds of the genotypes ranged from 63.43 to $87.24 \%$ at water deficit condition. Highest relative weight of 100- seeds was obtained from Binasoybean 1 (87.24\%), followed by Galarsum (86.79\%) and BU Soybean $1(67.01 \%)$ and lowest in BARI Soybean $5(63.43 \%)$.

Table 5. Seed yield and yield contributing parameters of soybean genotypes as affected by water stress

\begin{tabular}{|c|c|c|c|c|c|c|c|c|}
\hline \multirow[t]{2}{*}{ Genotypes } & \multicolumn{2}{|c|}{$\begin{array}{c}\text { Number of pod / } \\
\text { plant }\end{array}$} & \multicolumn{2}{|c|}{$\begin{array}{l}\text { Number of seed / } \\
\text { pod }\end{array}$} & \multicolumn{2}{|c|}{ 100-seed weight $(\mathrm{g})$} & \multicolumn{2}{|c|}{ Seed yield (g/plant) } \\
\hline & Control & $\begin{array}{l}\text { Water } \\
\text { stress }\end{array}$ & Control & $\begin{array}{l}\text { Water } \\
\text { stress }\end{array}$ & Control & $\begin{array}{l}\text { Water } \\
\text { stress }\end{array}$ & Control & $\begin{array}{l}\text { Water } \\
\text { stress }\end{array}$ \\
\hline $\begin{array}{l}\text { BU } \\
\text { soybean } 1\end{array}$ & 57.33 & $\begin{array}{c}37.00 \\
(64.53)\end{array}$ & 2.03 & $\begin{array}{c}1.83 \\
(90.15)\end{array}$ & 11.55 & $\begin{array}{c}7.74 \\
(67.01)\end{array}$ & 13.07 & $\begin{array}{c}5.41 \\
(41.39)\end{array}$ \\
\hline $\begin{array}{l}\text { Bina } \\
\text { soybean } 1\end{array}$ & 71.67 & $\begin{array}{c}46.78 \\
(65.27)\end{array}$ & 1.99 & $\begin{array}{c}1.89 \\
(94.97)\end{array}$ & 11.76 & $\begin{array}{l}10.26 \\
(87.24)\end{array}$ & 15.54 & $\begin{array}{c}6.52 \\
(41.96)\end{array}$ \\
\hline Galarsum & 81.67 & $\begin{array}{c}31.33 \\
(38.36)\end{array}$ & 2.02 & $\begin{array}{c}1.64 \\
(81.19)\end{array}$ & 11.66 & $\begin{array}{c}10.12 \\
(86.79)\end{array}$ & 17.28 & $\begin{array}{c}5.56 \\
(32.18)\end{array}$ \\
\hline $\begin{array}{l}\text { BARI } \\
\text { soybean } 5\end{array}$ & 76.33 & $\begin{array}{c}26.00 \\
(34.06) \\
\end{array}$ & 2.02 & $\begin{array}{c}1.59 \\
(78.71) \\
\end{array}$ & 11.21 & $\begin{array}{c}7.11 \\
(63.43) \\
\end{array}$ & 15.67 & $\begin{array}{c}4.59 \\
(29.29) \\
\end{array}$ \\
\hline $\operatorname{LSD}_{(0.05)}$ & \multicolumn{2}{|c|}{10.56} & \multicolumn{2}{|c|}{0.24} & \multicolumn{2}{|c|}{1.14} & \multicolumn{2}{|c|}{2.28} \\
\hline $\mathrm{CV}(\%)$ & \multicolumn{2}{|c|}{11.74} & \multicolumn{2}{|c|}{7.57} & \multicolumn{2}{|c|}{6.44} & \multicolumn{2}{|c|}{12.64} \\
\hline
\end{tabular}

Values in parenthesis indicate $\%$ of control

Seed yield

The highest yield under control condition was recorded in Galarsum (17.28 g) and the lowest in BU Soybean 1(13.07 g). On the other hand, under water stress condition Binasoybean 1 produced the highest yield $(6.52 \mathrm{~g})$ and the lowest in BARI Soybean $5(4.59 \mathrm{~g})$. Highest relative yield was obtained from Binasoybean 1 (41.96\%), followed by BU Soybean 1 (41.39\%) and Galarsum (32.18\%) and lowest in BARI Soybean 5 (29.29\%). The reduction of the yield per plant due to water stress was lower in Binasoybean 1 (58.04\%), while higher in BARI Soybean $5(70.71 \%)$. Drought stress in soybean reduced total seed yield and the branch seed yield (Frederick et al., 2001). In the present study, the reduction in seed yield under water stress was associated with number of pods per plant, number of seeds per pod and seed weight.

\section{Conclusion}

Soybean Var. Binasoybean 1 showed relatively higher water stress tolerance in respect of yield compare to other genotypes. Higher water content, proline and sugar accumulation in leaf as well as lower accumulation of malondialdehyde (MDA) contributed to the higher drought tolerance in Binasoybean 1 compare to other genotypes.

\section{Acknowledgement}


Physiological Basis of Water Stress Tolerance in Soybean

The research was carried out with the financial support of Research Management Committee (RMC), BSMRAU.

\section{References}

Abass, S. M. and H. I. Mohamed. 2011. Alleviation of adverse effects of drought stress on common bean (Phaseolus vulgaris L.) by exogenous application of hydrogen peroxide. Bangladesh J. Bot. 40 (1): 75-83.

Arora, A., R. K. Sairam and G. C. Srivastava. 2002. Oxidative stress and antioxidative systems in plants. Curr. Sci. 82: 1227-1238.

Bates, L. S., R. P. Waldren and L. D. Teare. 1973. Rapid determination of free proline for water-stress studies. Short communication. Plant and Soil. 39 (1): 205-207.

Delauney, A. J. and D. P. S. Verma. 1993. Proline biosynthesis and osmoregulation in plants. Plant J. 4(2): $215-223$

Farooq, M., A. Wahid, N. Kobayashi, D. Fujita, and S. M. A. Basra, 2009. Plant Drought Stress: Effects, Mechanisms and Management. Agronomy for Sustainable Development. 29: 185-212.

Frederick, J. R., C. R. Camp and P. J. Bauer. 2001. Drought-stress effects on branch and mainstem seed yield and yield components of determinate soybean. Crop Sci. 759-763.

Fuhrer, J. 2003. Agroecosystem Responses to Combinations of Elevated $\mathrm{CO}_{2}$, Ozone, and Global Climate Change. Agric. Ecosyst. Environ. 97: 1-20.

Gomez, K. A. and A. A. Gomez. 1984. Statistical Procedures for Agricultural Research ( $2^{\text {nd }}$ edition). International Rice Research Institute. John Willey and Sons, Inc. Singapore, pp. 139-240.

Gwathmey, C. O. and A. E. Hall. 1992. Adaptation to mid-season drought of cowpea genotypes with contrasting senescence traits. Crop Sci. 32: 773-778.

Heath, R. L. and L. Packer. 1968. Photoperoxidation in isolated chloroplasts. I. Kinetics and stoichiometry of fatty acid peroxidation. Arch Biochem Bioph. 125: 189-198.

Kishor, P. B. K., Z. Hong, G. Miao, C. A. A. Hu and D. P. S. Verma. 1995. Over expression of 1pyrroline-5- carboxylate synthetase increases proline over production and confers osmotolerancein transgenic plants. Plant Physiol. 108(4): 1387-1394.

Moussa, H. R. 2011. Low Dose of Gamma Irradiation Enhanced Drought Tolerance in Soybean. Acta Agron Hung. 59: 1-12.

Rohbakhsh, H. 2013. Alleviating Adverse Effects of Water Stress on Growth and Yield of Forage Sorghum by Potassium Application. Advances Environ Biol. 7(1): 40-46.

Schonfeld, M. A., R. C. Johnson, B. F. Carver and D. W. Mornhinweg. 1988. Water relations in winter wheat as drought resistant indicator. Crop Sci. 28: 526-531.

Somogyi, H. 1952. Notes on sugar determination. J. Biol. Chem. 195: 19-23.

Turk, K. J. and A. E. Hall. 1980. Drought adaptation of cowpea. IV: Influence of drought on water use and relation with growth and seed yield. Agron. J. 72: 440-448.

Velu, G. and K. Palanisami. 2002. Impact of moisture stress on growth and yield of sunflower. Madras Agric. J. 88 (10-12): 660-665.

Verslues, P. E., M. Agarwal, S. Katiyar-Agarwal, J. Zhu and I. K. Zhu. 2006. Methods and concepts in quantifying resistance to drought, salt and freezing, abiotic stresses that affect plant water status. The Plant J. 45(4): 523-539. 
Sarkar et al.

Zhu, J. K. and L. Xiong. 2002. Molecularand genetic aspects of plant responses to osmotic stress. Plant Cell and Environ. 25(2): 131-139.

Ziska, L. H. and A. E. Hall. 1983. Seed yields and water use of cowpea (Vigna unguiculata [L.] walp.) subjected to planned-water deficit irrigation. Irrig. Sci. 3: 237-245. 